\title{
Terrorist Framework and Inclination: The Behavourial Pattern of Boko Haram in Nigeria
}

\author{
Regis Chima Anyaeze \\ Spiritan University Nneochi (SUN), Nneochi, Nigeria
}

\begin{abstract}
Nigeria has witnessed a continuous deadly onslaught from Boko Haram since 2008. Boko Haram has survived three different administrations in Nigeria and has between 2008 and 2020 killed more than 54,000 people and displaced nearly two million in North-Eastern Nigeria. ${ }^{1}$ Since 2011, the sect has withstood Nigeria’s military and defense strategies with equanimity, claiming more than 200 Nigerian plus 92 military Chadian personnel, capturing and destroying more than \$200 million worth of military equipment. Military installations, open markets, religious-worshipping houses, government and defense institutions have remained consistent targets for Boko Haram's attack. The level of attacks, intelligence and near unbeatable approach being displayed by Boko Haram situate Boko Haram in de broader framework of international terrorism and depict a high level of negligence or compromise from the security institutions and the Nigerian state. The swapping of captives, striking of deals, negotiated release of Boko Haram captives, attempts at general or selected amnesty, and the huge benefits of political economy of terrorism equally suggest that Boko Haram has not only been an enemy, but a veritable partner of the Nigerian State, with its defeat not foreseeable anytime in the near future.
\end{abstract}

Keywords: terrorism, Boko Haram, Nigeria, security, behaviour

\section{Introduction}

Boko Haram has become a household name in Nigeria, Africa and globally. In Nigeria, people refer "Boko Haram" to persons who threaten others or cause others to panic. In public and private spheres, people scamper for their live at the shout of "Boko Haram"! These describe the level of insecurity and security alert that Boko Haram has occasioned in Nigeria. Alert, not in the sense of responding to ensured security, but rather in the sense of a level of consciousness devoid of security and safety-a reaction to hopeless situation. This is because the security personnel (police or military) has never prevented attacks or raids by Boko Haram or known to have carried out any swift operation to rescue victims of attacks or raids. The last two decades (more since 2012) has witnessed a collapse of national and sub-regional security owing to the activities of Boko Haram. The security situation has continued to degenerate, despite national, regional, and international efforts to contain the threats and activities of Boko Haram. Boko Haram has carried out more than 330 successful attacks and raids, more than 50 suicide attacks, destroyed more than 20 national and international symbols,

Regis Chima Anyaeze, Ph.D, Acting Head of Department, History and International/Diplomatic Studies, Spiritan University Nneochi (SUN), Nneochi, Nigeria.

1 Amnsesty International Report, 2015, https://www.amnesty.org/en/latest/news/2015/01/boko-haram-glance/; 2019, https://www.amnesty.org/en/countries/africa/nigeria/report-nigeria/; Internal Displacement Monitoring Centre (IDMC), Latest Global Report on Internal Displacement (GRID), 2012, https://www.internal-displacement.org/. 
captured and taken more 1,000 women (including schoolgirls), recruited more than 20,000 young men and women, displaced over 2,000,000 people including children, attacked and sacked more than five military bases, killing at least 152 soldiers, sacked more than 28 towns and villages, abducted more than 2,000 women, and once succeeded in erecting its flag in vast area (27 municipalities) of the northeast of Nigeria as a caliphate.

This paper is a result of a two-year participatory observation in Nigeria-Northeast, and a conscious intermingling with security operators at the frontline of the aggression against Boko Haram in Nigeria. It involved semi-structured interviews, semi-structured questionnaires, and visits to internally displaced persons (IDP) camps. The definitions and analysis of the activities and behaviour of Boko Haram as an organization and as insurgents are based on secondary literature.

The paper goes beyond ethnicism and religion in probing the activities of Boko Haram for a tally with global terrorist tendencies. Using historical examples and definitional and behavioural approaches, this paper examines the intentions behind the activities and ideologies of Boko Haram, and analyses how Boko Haram fits into the characteristics of the global terrorist framework.

\section{Boko Haram, Historical Background}

Prior to 2008, the name Boko Haram was not attached with any value in Nigerian politics and history. Boko Haram did not exist, or if it did, it made insignificant impact. Though religiosity (Islamic and Christian) have been part of Nigerian history, however, activities of fundamentalist sects occasionally were spontaneous and could be described as "hit and run" affair (Soyinka, 2012). According to Soyinka (2012), the fundamentalist Islamic sect that could come near to using religion to threaten national security in Nigeria was the Maitatsine ${ }^{2}$ of the 1980s. Using violence as strategy, Maitatsine, as a sect, felt divinely instructed by Allah to Islamize the country by killing and wiping out non-Muslims in Nigeria. In 1980, the civilian government of Shehu Shagari rose to the occasion, and mustered courage by confronting and defeating the Maitatsine sect. In 2008, a similar group sprang up in Borno State, northeast of Nigeria, with the name "Boko Haram". Literally translated, Boko Haram means "Western education is evil". A study of the Boko Haram at the inception of the movement in 2008 shows that it was mainly an Islamic group made up of local and illiterate almajiris (Islamic youth beggars), ${ }^{3}$ with the original mission to force everything Western out of Northern Nigeria. Following the same strategy of violence as Maitatsine, Boko Haram has added kidnapping, raiding, suicide bombing, and raping as strategies to force the northeastern population of Nigeria into submission.

In 2008, the group numbered about 500 and was led by an Islamic cleric called Mohammad Yusuf. With initial attacks on installations that had Western background, such as schools, hospitals, and police stations, the group never hid its motivation to target Western installations. In 2009, the Federal Government of Nigeria under President Umar Y'ardua militarily responded to the threats posed by Boko Haram and significantly reduced the capacity of the sect to carry out large scale attacks. The 2009 military victory against Boko Haram was not only as a result of political will by the then government to defeat the sect, but also because the sect could be regarded at the time as non-sophisticated and a rag-tag organization. As a result of the operation which also saw to the death of its leader Yusuf in a custody, Boko Haram seized to function as a deadly Islamic fundamentalist sect, and the name almost forgotten.

\footnotetext{
${ }^{2}$ Maitatsine, as a sect regarded non-Muslims as infidels, and therefore had no right; according to the fundamentalist Islamic rules, we know to them and find in their own Koranic versions.

${ }^{3}$ Refer to the speech of the Nigerian president on Boko Haram in the Paris Summit, CTV New, May 17, 2014.
} 


\section{The Resurrection of Boko Haram}

In April 2011, on the eve of the declaration by the Independent National Electoral Commission (INEC) of Nigeria of the winner of the 2011 presidential elections, believed to have been won by Goodluck Jonathan, parts of the North were thrown into violent attacks. The attacks which sounded as a protest and rejection of the new president from the Christian South resulted in many deaths. Members of the National Youth Service Corps (NYSC) deployed by INEC as ad hoc staff in various polling stations in the north became easy targets of attacks. The name Boko Haram resurfaces after the Nigeria's general elections of April 2011 to claim responsibility for the attacks. After the announcement of the new leader, Abubakar Shekau as the successor of the slain leader Yusuf, not all of Yusuf's followers joined Shekau because of split in the group. In 2015, Boko Haram was made up of six factions that sometimes collaborated for attacks, and sometimes came into conflict with each other. However, with massive recruitment and sympathy, Boko Haram became a new platform for various splinter groups to converge and launch terrorist attacks.

From random and irregular bomb blasts to semi-targeted attacks and the use of improvised explosive devices (IEDs) in 2008 and 2009, Boko Haram that was an illiterate group has by 2014 metamorphosed into an elite group capable of organizing, coordinating, and carrying out multiple attacks, with huge intelligence and first class logistics, powerful internal and external contacts, network and sponsorship. ${ }^{4}$ The fear in Nigeria became real that a humble group has been hijacked by some powerful political elites in the North (who lost in the political competition of 2011) to fight their clandestine political wars. ${ }^{5}$ From the precision of its attacks, the superiority of its weapons and the deadly nature of its activities, it became obvious that Boko Haram had moved from being a local fundamentalist rag-tag to a powerful "terrorist platform”, enjoying both domestic and global network in the global terror industry. ${ }^{6}$

Since April 2011, the northeastern part of Nigeria became a theater of regular attacks and siege by the new Boko Haram. As already mentioned, members of the National Youth Service Corps who took part in the Nigeria's 2011 general elections were the first targets, followed by non-Northern indigenes who became victims of targeted attacks, massacre, and expulsion from parts of the North. ${ }^{7}$ Northern political leaders and civil servants who refused to show strong sympathy to the course of Boko Haram equally became target of attacks. By 2015, the Northern part of Nigeria has witnessed an upsurge in insecurity including attacks on markets, churches and schools, raids on villages and military bases. These include the bombing of the United Nations headquarters, the Police headquarters and many Christian churches, one of which was the bombing of St. Theresa's Catholic Church Mandela on the Christmas day of 2011, with over 40 casualties. Markets, banks, police stations, motor parks, schools, and many public buildings have been destroyed in their hundreds with Boko Haram always at hand to claim responsibility and credit. Boko Haram has killed an estimated number of 7,000 civilians, with over 17 million displaced in more than 50 IDP camps, while property worth over 200

\footnotetext{
${ }^{4}$ The Nigerian president has in his various speeches to both local and international audiences equally made allusions that Boko Haram has metamorphosed and now operates in the same capacity as Al Qaeda.

5 Edwin Clark, an interview with the Sun Newspapers, June 15, 2014, Abuja Nigeria.

6 The Nigerian president Goodluck Jonathan and French president Hollande alluded that Boko Haram has strong ties and network with Al Qaeda, CTV News, May 17, 2014.

7 On January 5, 2012, 13 indigenes of Adazi, Anambra state were murdered in Mubi while holding an end of year party in Mubi, Adamawa state in the northeast. Owning the attack, Boko Haram announced that it was a warning for people from the southern part of Nigeria to leave the north, Vanguard, January 14, 2012.
} 
million dollars have been destroyed in random and targeted attacks in parts of Northern Nigeria. ${ }^{8}$ Perhaps the most discomforting was the kidnapping of over 270 schoolgirls in Chibok, Bornu State that attracted both national and international concern and condemnation.

Table 1

Activities of Boko Haram Between 2008 and 2020

\begin{tabular}{|c|c|c|c|c|c|c|c|c|}
\hline $\begin{array}{l}\text { Phases in } \\
\text { years }\end{array}$ & $\begin{array}{l}\text { No. of } \\
\text { insurgents }\end{array}$ & $\begin{array}{l}\text { No. of } \\
\text { targtes }\end{array}$ & $\begin{array}{l}\text { Type of } \\
\text { raids/bombings }\end{array}$ & $\begin{array}{l}\text { No. kidnaps } \\
\text { \& abductions }\end{array}$ & $\begin{array}{l}\text { No. of people } \\
\text { killed }\end{array}$ & No. of IDPs & $\begin{array}{l}\text { No. of local } \\
\text { governments } \\
\text { involved }\end{array}$ & No. of camps \\
\hline $2008-2011$ & 300 & 17 & soft & & & 0 & & \\
\hline 2012-2015 & 15,000 & 330 & $\begin{array}{l}\text { Soft/hard: villages, } \\
\text { schools, police } \\
\text { security posts, } \\
\text { military camps }\end{array}$ & 1,200 & 5,400 & & \begin{tabular}{|l}
15 local \\
government \\
areas in \\
north-eastern
\end{tabular} & 22 \\
\hline 2016-2020 & 20,000 & & $\begin{array}{l}\text { Hard: military bases, } \\
\text { police stations, } \\
\text { military/police } \\
\text { security posts }\end{array}$ & 800 & 1,600 & \begin{tabular}{|l}
2.7 million \\
in over \\
321,580 \\
households
\end{tabular} & $\begin{array}{l}\text { Vast area of } \\
\text { Sambisa } \\
\text { forest }\end{array}$ & 32 in borno \\
\hline
\end{tabular}

Note. Source: Adapted from Displacement Tracking Matrix, Round XX (Dec. 2017) and Round XXI of January 2018, https://www.internal-displacement.org/; Amnesty International Report 2015; Internal Displacement Monitoring Centre (IDMC), Latest Global Report on Internal Displacement (GRID) 2020, https://www.legit.ng/1142900-list-idp-camps-nigeria-locations.html.

\section{Boko Haram and Terrorism: Definition and Behaviour}

Though scholars are slightly in disagreement on the precise definition of terrorism, a few attributes of terrorism remain central. Following Viotti and Kauppi's (2009) and Baylis Smith, and Owens's (2008) definitions, we can generally view terrorism as the systematic use of terror, often violent, especially as a means of coercion to effect political change. Common definitions of terrorism refer only to those violent acts which are intended to create fear and terror and could be perpetrated for a religious goal, political, or ideological objective (Soyinka, 2012), and by deliberately targeting or disregarding the safety of innocent people and non-combatants (Hoffman, 2006). Some acts of unlawful violence and war, such as hostage taking and targeting of vulnerable institutions like schools and monuments have been included in the modern understanding and definition of terrorism. Somehow, the use of similar tactics by criminal organizations for protection, intimidation or to enforce a code of silence is usually not labelled terrorism, though these same actions may be labelled terrorism when done by a politically and ideologically motivated group (Hudson, 2002; Viotti \& Kauppi, 2009). Therefore, the difference between an organized crime and terrorism is clearly demarcated. ${ }^{9}$

Since 1994, the United Nations General Assembly (UNGA) has repeatedly condemned terrorist acts by insisting that:

Any criminal acts intended or calculated to provoke a state of terror in the general public by a group of persons or particular persons for political purposes are in any circumstance unjustifiable, whatever the considerations of a political, philosophical, ideological, racial, ethnic, religious or any other nature that may be invoked to justify them. ${ }^{10}$

\footnotetext{
8 Amnesty International Report, 2015.

9 While criminal gangs are motivated by economic gains, terrorist groups are politically motivated by seeking to violently overrun a legitimate government or induce political change. Cf. Viotti et al. (2009); Baylis et al. (2008).

10 Cf. UNSC Resolutions 1373 and 1456.
} 
For van Krieken (2010), any acts of terrorism are criminal and unjustifiable, regardless of their motivation, whenever and by whomsoever committed and are to be unequivocally condemned, especially when they indiscriminately target or injure civilians.

Based on the above definitions of terrorism, Soyinka (2012) insisted that Boko Haram has carried its activities in Nigeria based on political, philosophical, ideological, and religious considerations (Soyinka, 2012). The targets of its attacks have been both religiously, ideologically, and ethnically based as their initial targets were members of other religions, ethnic, and social orientations. Leaders and commanders of Boko Haram have equally on several video broadcasts threatened to forcefully make Nigeria an Islamic state, in contradiction to the wish and freedom of the Nigerian people to choose and practice their religions as enshrined in the Nigerian Constitution (Ezeanokwasa, Ewulum, \& Mbanugo, 2016). ${ }^{11}$ The purported forceful conversion of the kidnapped Chibok schoolgirls, as shown on the publicized video of May 7, 2014 by the leader of Boko Haram-Abubakar Shekau, gives credence to the intention of Boko Haram as an ideological and religious war.

In November 2004, the United Nations Secretary General in his annual report described terrorism as: "any act intended to cause death or serious bodily harm to civilians or non-combatants with the purpose of intimidating a population or compelling a government or an international organization to do or abstain from doing any act" ${ }^{\prime 2}$.

Since 2008, Boko Haram has inflicted deadly harm to civilians and non-combatants with more than 330 attacks and 7,000 deaths, ostensibly to intimidate and compel the government to abstain from its work, to influence a seeming political change, and to derail the democratic process in Nigeria. Boko Haram has also on 12 different occasions boasted and threatened to sack a legitimate Nigerian government, promising to replace an elected government with a caliphate, and went ahead to erect a caliphate in more than 18 local governments in the North east of Nigeria in 2014.

Boko Haram attacks Nigeria's northeast, not solely because of religious and political reasons, but also because of the interaction between democracy and terrorism, which Shabad and Ramo (1995) described as a fight for supremacy. Democracy supports human freedom and human rights which adherents of fundamentalism mostly oppose and object to (Soyinka, 2012), since oppression and suppression seem attributes of fundamentalism. Boko Haram represents this view and ideological locus-standi. Therefore, the relationship between domestic terrorism represented by Boko Haram, and democracy which represents freedom in Nigeria remains very complex as seen in the ideology of Boko Haram to suppress religious freedom, block access to education and repress women in northern Nigeria by targeting churches and kidnapping schoolgirls to send out stern warning to girls to shun education and freedom. Nigeria is still on the consolidation stages of its democracy, and therefore a clear target of terrorism, corresponding to Shabad's opinion that terrorism festers most commonly in nations with intermediate political freedom, and least common in stable and consolidated democracies (Shabad \& Ramo, 1995). ${ }^{13}$

In his analysis of terrorist organizations, Hoffman (1998; 2003; 2006) identified some key characteristics of terrorist organizations, arguing that by distinguishing terrorists from other types of criminals, and terrorism from other forms of crimes, we come to appreciate that terrorism is:

11 Cf. Sections 37, 38, 41, and 42 of the 1999 Constitution of Federal Republic of Nigeria (as amended) on "Freedoms".

12 Cf. UNSG, Annual Report 2004.

13 Refer also to the article, "Poverty, Political Freedom, and the Roots of Terrorism” (2004). Here the argument is made explicit, that there is a correlation between terrorism against the desire for political and social freedom. 
- ineluctably political in aims and motives;

- violent and indiscriminate, designed to have far-reaching psychological repercussions beyond the immediate victim or target;

- conducted by an organization with an identifiable chain of command or conspirational cell structure, whose members wear no uniform or identifying insignia;

- perpetrated by a sub-national group or non-state entity.

The capture of some disguised male and female sympathisers, intending on blowing up themselves in suicide attacks to create and expand public panic and fear among the public in Nigeria provides further clue on the inclination and behaviour of Boko Haram. ${ }^{14}$ The bombing of 17 churches, 12 open markets, seven motor parks, and more than 30 public buildings in parts of Nigeria, including the police headquarters and UN office in Abuja all have the trappings Hoffman's characteristics of terrorism, and have further inflicted psychological pains on individual families and the Nigerian state.

Book Haram has identifiable chains of command. After the death of its first commander in 2009, Boko Haram has since witnessed the succession of leadership each time a commander was either wounded or liquidated. The current political and spiritual leader, Abubakar Shekau, served previously as a deputy commander, taking power after the previous leader, Mohammad Yusuf was killed in custody by the Nigerian police in 2009. Abubakar heads the council of elders called Shura.

Boko Haram qualifies as an identifiable non-state entity, therefore possesses no legal rights to carry arms or use violence against the Nigerian state and its population. According to the principles of International State system, and in consonance with the 1999 Nigeria's constitution as amended, only the state, through its security agencies, are bestowed with the legitimate use of force, and therefore permitted to bear arms as stipulated in the Nigerian constitution to provide peace and security to the nation ${ }^{15}$.

The activities of Boko Haram could further be considered conspiratorial, with an aim to forcefully engineer both religious and political change in Nigeria. Therefore, a definition proposed by Bockstette (2008), which underlines the psychological and tactical aspects of terrorism fits in all intents and purposes, the activities of Boko Haram as a terrorist group. Bockstette (2008) defined terrorism as "political violence in a situation of asymmetric conflict, designed to induce indiscriminate terror and psychic fear through the violent victimization and destruction of innocent targets, including, sometimes iconic symbols” (p. 3).

By analysis, we can understand why Boko Haram attacks churches, mosques, schools, markets, motor parks and other public buildings. The targeted attacks on schools and the kidnapping of schoolgirls were strong signals and message from Bako Haram to terrorized families and to every girl in northern Nigeria to think twice and to consider education a zero option.

Just as other terrorist organizations do, Boko Haram enjoys media hype. With media hype, wide broadcast and audience, a terrorist organization gains more confidence and considers itself successful (Bockstette, 2008). Osama bin Laden enjoyed a kind of media hype and attention, which he readily signified by how he raised his hand and flag each time major media houses broadcast his terrorist activities around the world, with ensuing media analysis. The regular release of video clips by Osama bin Laden was meant to serve this purpose. The

\footnotetext{
14 Between 2013 and 2019, there were 124 incidents of suicide attacks by mail and female sympathizers of Boko Haram, including underage and brainwashed girls between 8 and 17 years old. In 2018, 48 children were used as human bombs by Boko Haram, including 38 girls. Cf. BBC news Nigeria: “Children used” as suicide bombers in Borno attack, 18 June 2019.

${ }^{15}$ Section 14(2)(b) of the Constitution of the Federal Republic of Nigeria, 1999 (as amended)
} 
leaders of Boko Haram, including the current leader-Abubakar Shekau, all adopted this strategy to attract attention and expand public anxiety. As Bockstette (2008) noted, "Terrorist organizations exploit the media in order to achieve maximum and attainable publicity by engaging in activities that attract wider audience and public outcry” (p. 3), further insisting that media hype and attention as strategy serve as an amplifying force with a multiplier effect capable of influencing and inducing the targeted audiences into negotiating short- and midterm political goals and desired long-term ends (ibid). The bombing of the UN office, police headquarters, and motor parks in the Nigerian capital city of Abuja, and the kidnapping of vulnerable Chibok schoolgirls were meant to create media hype, and therefore force the government into a negotiation, capable of serving a short or midterm political goal for Boko Haram. ${ }^{16}$

Research into the motives of terrorists has shown that terrorist attacks usually are planned and executed to maximize the severity and length of psychological impacts on their victims and on the state (Hoffman, 2003; 2006; Viotti \& Kauppi, 2009; Baylis et al., 2008). Each act of terrorism is therefore a calculated attempt devised to have an impact on many large audiences and layers of society. Mostly, international and national symbols are targeted, simply to induce humiliation and inflict psychological pains on national or international psyche. The targeted attacks by Al Qaeda on the World Trade Centre, the Pentagon, the foiled attempt to hit the White House in Washington in the US, and the various attacks on US embassies outside the United States were possibly meant to induce humiliation and pain on the US. We can adduce the same intention to the targeted attacks of Boko Haram on the Police Headquarters and the UN office in the Nigeria's capital city, Abuja. The goal possibly was to show power and supremacy, to belittle the Nigerian security network, and to attempt to induce humiliation and pain on the Nigerian psyche. While such attacks negatively affect a government and increase national anxiety, they increase the prestige of the given terrorist organization and sharpen its ideology. For instance, the members of Boko Haram must have had "real fun” watching the Nigeria's First Lady, Patience Jonathan, publicly shed tears in 2014, in reaction to the kidnapped Chibok schoolgirls. ${ }^{17}$ The Nigerian former president, Goodluck Jonathan, felt visibly humiliated when Boko Haram leader Abubakar Shekau in 2013 rejected government's offer of amnesty for Boko Haram members. $^{18}$

Terrorist events of the last two decades in Nigeria have shown that terrorist acts frequently have a political purpose, though mostly not conducted in a political tactic, like protest-write ups and street protests, which activists use as the last resort to influence a desired change. Terrorists opt for a different strategy. According to Hoffman (2003), terrorists tend to believe that a certain desired change is so urgent that failure to achieve the intended change is seen as a worse outcome than the deaths of innocent people. Hoffman argues that terrorist groups in general, operating globally or domestically, often consider the death of innocent people as a vehicle for a desired change. For instance, the number of innocent lives lost on the hijacks of 9/11 did not matter for Al Qaeda if the US probably could be pressurized to change its foreign policy, especially in the Middle East (Yoo \& Ho, 2003). Likewise, the number of innocent Nigerian citizens that have died in various attacks was not meant to matter for Boko Haram if the Nigerian state could be pressured to profess Islamism or give in to the

\footnotetext{
${ }^{16}$ The defeat of an incumbent president of southern extraction by a presidential candidate of northern extraction could not be far from a short and even, midterm political goal of the sponsors of Boko Haram.

17 The image of the First Lady shedding tears in the public has been turned into a national comedy by many musicians and comedians.

18 Cf. BBC News Africa: Nigeria’s Boko Haram rejects Jonathan's amnesty idea, April 11, 2013, https://www.bbc.com/news/world-africa-22105476.
} 
articulated demands of Boko Haram, like the abolition of schools for girls and the recognition of Nigeria as their caliphate.

The combination of religion and ideology creates a complex web of interaction that often disposes the society into manipulation, rendering it a willing tool for terrorist organizations. Religion thrives on sentiments and emotions. Often, people rise to defend their religion even when it is obvious that a particular religion has become a vehicle for the conveyance of dangerous ideology (Soyinka, 2012). Religion, when mixed with ideology, assumes huge capacity to exact pressure in a complex interwoven and symbiotic relation where both feed on and from each other. As Soyinka (2012) observed, "The religious and ideological goals of Boko Haram exact much pressure and appears embedded in the activities of Boko Haram because of a symbiotic relationship between terrorism and religion". He argues further that such a pressure becomes prominent when a political struggle becomes integrated into the framework of a religious or "cosmic struggle", such as over the control of a region as in the fight of control over some of the federating states in northern Nigeria by Boko Haram. Therefore, failing in the political goal may become equated with spiritual failure, "which, for the highly radicalised and fundamentalists religionists, is considered worse than their own death or the deaths of innocent civilians” (Hoffman, 2003; 2006). Boko Haram fighters and sympathizers have increasingly engaged in suicide attacks and many more appear ready to die for their course. Their failure at this stage of their radicalized struggle ultimately would mean a spiritual death. ${ }^{19}$ To give up on the fight ultimately means a spiritual death, worse even than their own deaths and a promise of 72 virgins in the paradise. In rejecting government amnesty proposal in 2013, the supreme leader of Boko Haram Abubakar Shekau said: "It was the Nigerian government that was committing atrocities against Muslims. Surprisingly, the Nigerian government is talking about granting us amnesty. What wrong have we done? On the contrary, it is we that should grant you pardon”,20, expecting any remorse or change of attitude from Boko Haram sounds foolhardy, not even with amnesty and negotiation from the government.

Book Haram, originally a national terrorist organization, which now operates across border is an ideology that started by targeting against anything "Western". The initial objective was to conquer and Islamize the Nigerian state (Soyinka, 2012). Since it lacked the political power to achieve this objective, a resort to violence and intimidation became a veritable medium to force down the dream on "infidels". Soyinka argues that the initial or "original victims of Boko Haram were targeted not because they were threats, but because they were specific 'symbols, tools, animals or corrupt beings' that tie into a specific world view that Boko Haram possessed” (Soyinka, 2012). For Boko Haram, the suffering of the innocent people accomplishes their goals of instilling fear, getting their message out to a wider audience, or otherwise satisfying the demands of their often-radical religious, ideological, and political agendas.

\section{Can a Terrorist Act of Any Kind Be Justified?}

Relying on newspaper reports, social media, and opinion pools and semi-structured interviews, a section of the Nigerian public appears to sympathize with the course of Boko Haram but detest Boko Haram's

\footnotetext{
${ }^{19}$ Cf. Chadian Army Kills More Boko Haram Terrorists as Shekau Begs Fighters not to Run in New Audio, Sahara Reporters, New York, April 2020, http://saharareporters.com/2020/04/05/chadian-army-kills-more-boko-haram-terrorists-shekau-begs-fighters-not-run-new-audio. 20 Ibid.
} 
indiscriminate targets on the innocent Nigerian population ${ }^{21}$. In other words, if Boko Haram could target government and security officials and their families, believed to be the cause of Nigeria's agony for reasons bothering on corruption and bad governance, perhaps, many would be willing to support Boko Haram ${ }^{22}$. "If Boko Haram would do this by 'meaningfully' targeting its grievance, then many in the Nigerian public would cease to refer to the group as a terrorist organization and perhaps ascribe to them as "freedom fighters". ${ }^{23}$ Boko Haram therefore would become a liberation movement or an opposition group if the populace could rely on the terrorist group for the execution of a common agenda, sacking the, or taking a pound of flesh from the ruling class. Following Hoffman's characteristics of terrorism, Boko Haram could have garnered heroic respect from the public if not for the indiscriminate nature of its attacks that appear awful to the public. The indiscriminate attacks make Boko Haram a terrorist group because attacks on civilian targets, like markets, banks, churches, schools, and villages fit into the description of terrorism and UN Resolutions 1373 and 1456.

Another debate across Nigeria claims that Boko Haram, despite its attacks, whether targeted or indiscriminate, could not fit into the description of terrorism. This perspective maintains that Boko Haram as a sect possesses a genuine grievance and so merits some level of sympathy, and possibly an amnesty as accorded to some other militant groups in the Niger Delta of Nigeria in 2009 (Kperogi, 2018) ${ }^{24}$. Through a genuine and sympathetic opinion, many scholars and security experts have opposed such a debate and argument, viewing it as clearly distorting any meaningful understanding of terrorism, security, and the use of force. ${ }^{25}$ In comparison to Boko Haram, other militant groups in the Nigeria's Niger Delta were essentially different in terms of mission, agenda, strategy, the use of force, targets of attack and grievance. The militant groups in the Niger Delta were pressure groups that had clear objectives and end desires: resource control, environmental protection, and youth empowerment (Obi, 2009). ${ }^{26}$ Their objectives were made public, while their grievance was directed and targeted. A research into the aims and objectives of the militant groups in the Nigeria's Niger Delta suggests no meeting point between the movement and militancy in the Niger Delta with Boko Haram in the Nigeria's Northeast.

To what extent then can a terrorist act, such as killing civilians be justified as the lesser evil in a particular circumstance? Philosophers and terrorism experts have expressed different views concerning this kind of situation. For Soyinka (2012), "No matter the motivations, no matter the extra-motivations of those who send them out, terrorist acts cannot be justified, because the only one motivation is to kill”. Rodin (2006) theoretically conceived of cases in which the good which could not be achieved in a less morally costly way outweighs the evil of terrorism. Rodin argues further that the "harmful effects of undermining the convention of non-combatant immunity, by targeting innocent citizens and civilians is considerably thought to outweigh the goods that may be achieved by particular acts of terrorism” (p. 5). On the other hand, Walzer (2000; 2004a; 2004b) argued that terrorism as an option can only be considered in one specific case when a nation or community faces the extreme threat of complete destruction and extinction. Walzer (2000; 2004a; 2004b)

\footnotetext{
${ }^{21}$ Author's interview with a prominent Nigerian residing in the Netherlands on the possibility of supporting of fighting against Boko Haram in Nigeria. Eindhoven, The Netherlands.

${ }^{22}$ A professor of sociology confirmed to the author that he would volunteer to provide intelligence services to Boko haram if the group would become more focused with their targets, especially the ruling class and their families-interview.

23 Ibid.

${ }^{24}$ Cf. International Centre for Investigative Reporting (ICIR): Amnesty for Boko Haram? That’s unconscionable! April 28, 2018.

25 Ibid.

26 Declaration of the Mission and goal of the Movement for the Emancipation of the Niger Delta (MEND).
} 
argued that if a terrorist act appears to be the only way a nation or a community can preserve itself by intentionally targeting civilians and non-combatants, such a strategy can then be excused or justified in such a situation.

However, though situations of extreme threat of complete destruction of a community has occurred in history to warrant, excuse, or justify acts of terrorism on non-combatants as a strategy, resort to such a strategy has been rare. The non-utilitarian option therefore raises the obvious question of the motivation behind the activities of Boko Haram. Are communities in the north-eastern part of Nigeria under threat of complete destruction? Has Boko Haram any genuine grievance against the Nigerian state or society? Is Boko Haram's grievance rooted in its ideological shenanigan embedded in its name: "away with western influence”? We may extend the question to interrogate the second generation of motivation behind Boko Haram. For instance, has the group been hijacked by other more powerful hidden groups or persons for political ends?

If Boko Haram as an "entity" existed, it was neither under threat nor at war with any government agency whether national or local before the inception of violence against the Nigerian state and its population in 2008. Though perspective into the poverty level and backwardness of the north-eastern region has figured as a palpable reason for Boko Haram's attack on innocent people, experts think that linking poverty as a reason for terrorist acts smacks of integrity and only a political ploy to access the political economy inherent in war or conflict economies (Kisangani \& Nafziger 2007; Obi 2009). Poverty exists everywhere, with terrorism increasing the tally of poverty, oppression, and ignorance. Research shows that the commanders and sponsors of Boko Haram are not poorer than most Nigerians. Moreover, Boko Haram has not come forward to declare that poverty has been the reason for its terrorist war against the Nigeria state and the innocent civilian population.

\section{Labelling and Declaring Boko Haram a Terrorist Organization}

While "terrorism" connotes a state of action, "terrorist" refers to someone who engages in the action (terrorism), thus carrying strong negative connotations. In general, the two terms are used as political labels to condemn violence or the threat of violence by certain actors as immoral, indiscriminate, and unjustified (Hudson, 2002, United Nations Security Council [UNSC] Resolution 1373 and 1456). The terms are further used to condemn an entire segment of a population if such a population supports or harbours people who engage in defined acts of terrorism or unacceptable acts. ${ }^{27}$ When the Nigerian state, experts, and various segments of the Nigerian and international community condemned the activities of Boko Haram as terrorism, this was ostensibly done because the activities of Boko Haram were at best immoral, indiscriminate, unprovoked and therefore unacceptable and cannot be justified as Resolutions 1373 and 1456 of UNSC stipulate.

However, those labelled "terrorists" by their opponents rarely identify themselves as such, and typically use other terms to describe their specific actions, though, this does not make such actions redeemable. Boko Haram, like other terrorist groups, such as Al Qaeda, ISIS, and El Shabbab, refers themselves to as "Jihadists". In the political lexicon, words, such as jihadists, separatist, believers, freedom fighters, liberators or revolutionary forces, vigilante, militant, paramilitary, guerrilla, rebel, patriot, or any similar word in other languages and cultures have become common and popular political phrases. This is mainly because terrorists and their sympathisers view their own actions differently. Jihad, Mujahedeen, and Fedayeen are similar Arabic

27 After the unsuccessful attempt by a Nigerian, Abutaleb, to blow the US bound plane on December 25, 2012, the US authority placed Nigeria on the terrorist list, ostensibly, an indication that Nigeria habours terrorists. 
words which have entered the English political lexicon. They are mainly used to divert attention away from terrorist tendencies. How the group labels itself (like the friendly term of jihadists) does not necessarily matter and does not make the group less terrorists. It is common that parties in a conflict describe each other as terrorists, just as the commander of Boko Haram has severally and consistently described the Nigerian state and the Military Task Force as the "real terrorists". However, terrorism is not attributed by terms or words, but by actions and activities ${ }^{28}$. The act of carrying out large scale violent and indiscriminate activities that result in hundreds of deaths and psychological fears remain terrorist by all intent and inclination. ${ }^{29}$

The tendency for terrorist groups to present their actions in friendly and sympathetic terms, and force a section of the populace to view it that way is perhaps why the term terrorism remains distorted despite its horrendous impacts and the horror it exhumes. In his book Inside Terrorism, Bruce Hoffman (2003; 2006) offers an explanation why the term terrorism becomes distorted and remains so, even though, at least, everyone agrees that terrorism is a pejorative term. According to him, “...the term projects negativity and generates intrinsically negative connotations that are generally applied to one's enemies and opponents, or to those with whom one disagrees and would otherwise prefer to ignore.” (Hoffman, 2006, p. 23).

Brian Jenkins (2006) concurs with Hoffman that is called terrorism seems to depend on one's point of view. Owing to the burden of scorn, the use of the term increasingly implies a moral judgment. However, with the support of power relation, ${ }^{30}$ if one party can successfully apply the labels "terrorism" or "terrorist" to an opponent, it can indirectly persuade others to adopt its moral viewpoint if imbalance exists in power relation. Boko Haram as a non-state actor does not share equal power relation with the Nigerian state. The Nigerian state has the monopoly of violence with agencies that make laws and prescribe punishment. It was easier for the Nigerian state and other stakeholders in the Nigerian security project to successfully label Boko Haram as a terrorist organization, and to further convince and invite other stakeholders in the regional and international community to accept and cooperate in the fight against Boko Haram as a domestic and international terrorist group. Boko Haram, as a non-state actor, does not enjoy such a privilege of supporting its labelling with effective implementation as a state actor would do despite its international network.

In Nigeria, many have referred to some militant groups, like the Movement for the Emancipation of Niger Delta (MEND) and the Movement for the Sovereign Survival of Biafra (MOSSOB) as terrorist groups. The acceptance or refusal of such labelling has depended largely on power relation. The Nigerian state has in 2018 declared IPOB a terrorist organization but was unable to convince stakeholders in the international community to follow suit. ${ }^{31}$ The actions and activities IPOB supposedly did not sufficiently fit into terrorism definitions.

\footnotetext{
${ }^{28}$ In 2013, Boko Haram leader rejected Nigeria's offer for amnesty, claiming that the government was the real terrorist and therefore needed amnesty for Boko Haram whom he referred to as jihadists and liberators. BBC World News, Africa, April 11, 2013, https://www.bbc.com/news/world-africa-22105476.

${ }^{29}$ Refer to Hoffmans' description and characteristics of terrorist acts in page 6.

${ }^{30}$ Power relations are the interactions between different groups in a society. Power relations exist at all levels of society and concern the ability of one group or a person to control others. These relations exist in societies around the world and among states in the international state system. Thus, power relations take place in interpersonal relationships, among members of a community and on larger scales. They can be associated with gender, socioeconomic status, political status and more. In places where different groups live together, one is more likely to exert control over the others. With reference to this topic, power relation is associated with political, economic and power imbalance that exist between state and non-state actors in using instruments of government as an advantage.

31 The Nigerian state declared IPOB a terrorist organization on September 15, 2017 through a press release by the Director of Defence Information (DDI), Maj. Gen John Enenche. Cf. The Guardian, September 16, 2017, Premium Times, September 15, 2017, Abuja, Nigeria.
} 
In other words, the decision to call someone or label a particular organization as "terrorist" can become almost unavoidably subjective, and can largely depend on whether one sympathizes with or opposes the person or organization concerned (Jenkins 2006; Hoffman, 2006). An attempt to identify with the victim of a particular violent act, for instance, could present the act as terrorism. On the other hand, a show of sympathy for the perpetrator could turn the violent act into a more sympathetic and often positive light, and therefore not a terrorist act. Thus, it may not be surprising that sympathisers of Boko Haram do not consider any acts by the group as terrorism, indicating that taking side with the perpetrator may blind the observer to objectively judge an issue correctly.

The pejorative connotations of the term terrorism can therefore be summed up in the aphorism, "One man's terrorist is another man's freedom fighter” (Rudner, 2008; Humphreys, 2006, Friedersdorf, 2012; Wikan, 2018). Historical examples help us here to understand this dictum closely.

Several groups that adopted irregular military methods have in history suddenly become allies of the state against a mutual enemy. There is a record of how some of those groups later fell out with the state, to become enemies of the state, and went on to use the same violent methods against their former allies. Clark (2007) had given an account of an event during the World War II, where the Malayan People's Anti-Japanese Army allied with the British against Japan, a mutual enemy at the time. Unfortunately, later, during the Malayan Emergency, the same British branded as "terrorists", the members of the Malayan Races Liberation Army, who were the successors of the Malayan People’s Anti-Japanese Army. ${ }^{32}$ Same was the case in the relationship between the US and Afghan Mujahideen in the 1980s. During their war against the Soviet Union, the US president Ronald Reagan and others in the American administration and intelligence service frequently called the Afghan Mujahideen including Osama bin Laden "freedom fighters". 33 Yet 20 years later, when a new generation of Afghan men and women began to fight against a regime perceived to be a stooge of foreign powers, the Mujahideens were labelled "a terrorist group” by George W. Bush. ${ }^{34}$ Chouvy (2009) had shown with Afghanistan that “...an unbiased look at terrorism in Afghanistan reveals that many of those labelled terrorists' were individuals or groups once regarded as 'freedom fighters', 'struggling against the Soviets during the 1980s” (p. 119). In 2018, the Nigerian State labelled the group, Indigenous People of Biafra (IPOB) a terrorist organization, even though many believe that IPOB by its activities did not show any untoward signs of a terrorist group. ${ }^{35}$ Recently, America and Iran have declared a section of state agencies of each other as terrorists. While America declared the Iranian military as a terrorist group, Iran in retaliation designated all American military troops in the Middle East as terrorist groups. ${ }^{36}$ Who blinks first in this show of supremacy

32 See also The Britannica Concise: Malayans peoples Anti-Japanese Army.

33 Refer also to the speech delivered by Ronald Reagan on March 8, 1985 to National Conservative Political Action Conference. Retrieved from Spartacus Educational Website.

34 “President Bush Meets Afghan Interim Authority Chairman.” January 29, 2002, https://georgewbush-whitehouse.archives.gov, Accessed June 26, 2020.

35 The reasons for declaring IPOB a terrorist organization include: the formation of a Biafra Secret Service; formation of Biafra National Guard; unauthorized blocking of public access roads; extortion of money from innocent civilians at illegal road blocks, militant possession and use of weapons (stones, molotov cocktails, machetes and broken bottles among others) on a military patrol; physical confrontation of troops by the leader and other IPOB actors at a police checkpoint and attempts to snatch their rifles. Gaurdian News Newspaper, September 16, 2017, https:/guardian.ng/news/military-declares-ipob-terrorist-group/, Premium Times, $\quad$ September 2017, https://www.premiumtimesng.com/news/headlines/243351-nigerian-military-declares-ipob-terrorist-organisation.html.

36 Cf. Reuters-World News "Iran designates as terrorists all US troops in the Middle East (Iranian President Hassan Rouhani signed a bill into law on Tuesday, April 30, declaring all U.S. forces in the Middle East terrorists and calling the US government a sponsor of terrorism. https://www.reuters.com/article/us-usa-iran-rouhani-idUSKCN1S61GB. 
and power depends largely on power relation and global economic strength to mobilize allies to do the same.

"Terrorism and terrorist" as activities and terms have in history witnessed evident mutation. The mutation of terrorism and terrorist has depended on who is imposing the burden of meaning on the activities of a given organization. As pointed out earlier, power relation has played key role in swinging the mutation. The more political power an entity wears, the more leverage the entity has in determining, labelling, and giving meaning to the labelling. For instance, as long as the Nigerian state (politically more powerful in this case) has labelled Boko Haram a terrorist organization and subsequently imposed the burden of this term on Boko Haram, and has caused others to see and consider Boko Haram as a terrorist group, Boko Haram as a group or an organization would continue to carry the burden of such a stigma as a public enemy, until the state withdraws such a label. This remains so even as Boko Haram understandably prefers terms reflecting legitimate or ideological action, as jihadists. The argument that one man's terrorist is another man's freedom fighter and ones official's refugee is another's terrorist appear misleading, because the validity of the cause of terrorism seems to be assessed when terrorism is only an act (Rudner, 2008). In this sense, an organization or someone can have a perfectly beautiful cause, yet if one or an organization indulges in or commits any of the acts associated with terrorism, it becomes terrorism regardless of the intention (UNSC Resolutions 1373 and 1456).

No wonder, many individuals who today are celebrated as public icons were once labelled terrorist mostly by some Western governments or media on account of their involvement in a "liberation” struggle. Ironically, some persons labelled terrorists, have, long time later, as leaders of liberated nations, been referred to as "statesmen" by similar governments and media organizations. Two examples stand out in history. The Noble Peace laureates Menachem Begin and Nelson Mandela were labelled terrorists by some world leaders and media (Ahmed, 2002). ${ }^{37}$ The Wiki Leaks whistle-blower Julian Assange was on several occasions labelled and referred to as a "terrorist" by Sara Palin and the former US vice president, Joe Biden (Beckford, 2010; MacAksill, 2010). However, some of the formally labelled "terrorists" have proved to be successful political leaders of their countries and later, became good friends of those who labelled them as terrorists. ${ }^{38}$ Further, states that have been close allies for reasons of history, culture, and politics, have equally disagreed over whether or not members of a certain organization could be labelled as terrorists (Cass, 1997). For instance, for many years, some branches of the United States government refused to label members of the Irish Republican Army (IRA) as terrorists while the IRA, which the United Kingdom (UK) branded terrorist, continued to direct terrorist attacks on the UK, the closest ally of the United States (McCabe, 2003).

The media outlets are not left out in the politics of terrorist labelling and branding. Depending on which side they stand, media outlets wishing to preserve a reputation for impartiality try to be careful in their use of the term terrorism for organizations that enjoy sympathy with big powers. As such, many political leaders, and media outlets of northern extraction in Nigeria have remained so silent and careful in condemning or contributing to any genuine debates and discussions that would portray the activities of Boko Haram as terrorist acts.

\footnotetext{
37 The former British Prime Minister Margret Thatcher and former US president Ronald Regan referred to Mandela and his struggles in South Africa as terrorist act.

${ }^{38}$ Lord Desai Hansard has referred to Jomo Kenyetta, Nelson Mandela and Menachem Begin as examples of successful statesmen who were once denounced as terrorists by some "powerful” world leaders like Margret Thatcher and Ronald Reagan.
} 


\section{Conclusion}

The paper has attempted to give a background of the formation and metamorphosis of Boko Haram into a deadly terrorist movement. The paper has further discussed Boko Haram as a terrorist organization using historical, research, and behavourial analysis to situate Boko Haram within the framework of global terrorist modus operendi. The battle to rescue Nigeria from the clutches of Boko Haram rages. With expansion and in number, sophistication in logistics and weaponry, the religious and ethnic disparity in Nigeria, the expansion of Boko Haram's influence into three neighbouring countries of Cameroun, Chad, and Niger, and the inherent political economy of conflict, defeating Boko Haram be hectic while Boko the security situation in Nigeria continuous to look grim. As “One man’s terrorist remains another man’s freedom fighter”, in the ongoing insecurity and terrorism in Nigeria, only a political will reminiscent of that of Umar Y'ardua in 2009 would deter Boko Haram in Nigeria.

\section{References}

Abraham, M. (2008). What terrorists really want: Terrorist motives and counter terrorism strategy. International Security, 32(4), 86-89.

Ahmad, Eqbal (2002, January). “Straight Talk on Terrorism.” Monthly Review. Archived from the original on February 5, 2012. Accessed June 26, 2020, from https://www.questia.com/magazine/1G1-82137013/straight-talk-on-terrorism

Ali, K. (1987). A theory of international terrorism. Connecticut Law Review, 19, 945.

Baylis, J., Smith, S., \& Owens, P. (2008). The globalization of world politics: An introduction to international relations (4th ed.). Oxford: Oxford University Press.

Beckford, M. (2010). Hunt Wiki Leaks founder like Al Qaeda and Taliban leaders. London: The Telegraph.

Blin, A., \& Chaliand, G. (2007). The history of terrorism: From antiquity to Al Qaeda. Berkeley: University of California Press.

Bockstette, C. (2008). Jihadist terrorist use of strategic communication management techniques. George Marshal Centre Occasional Paper Series 20. ISSN 1863-6039

Cass, F. (1997). The media and terrorism: A reassessment. Terrorism and Political Violence, 9(2), 51-64.

Chouvy, P. A. (2009). Opium: Uncovering the politics of the poppy (illustrated \& reprint, ed.). Harvard: Harvard University Press. ISBN 978-0-674-05134-8

Clark, C. (2007). “Malayan Emergency, June 16, 1948. Archived from the original on June 8, 2007, June 16, 2003.

English, R. (2007). Irish freedom. London: Pan Books.

Ezeanokwasa, J. O., Ewulum, B. E., \& Mbanugo, O. O. (2016). Religious freedom and its limitations under the 1999 constitution of Nigeria. Nnamdi Azikiwe University Journal of International Law and Jurisprudence (NAUJILJ). Retrieved from https://www.ajol.info/index.php/naujilj/article/view/136239

Friedersdorf, O. (2012). Is one man's terrorist another man's freedom fighter? The Atlantic. Retrieved from https://www.theatlantic.com/politics/archive/2012/05/is-one-mans-terrorist-another-mans-freedom-fighter/257245/

Brian Michael Jenkins, B.M “Unconquerable Nation: Knowing Our Enemy, Strengthening Ourselves,” RAND Corporation (MG-454), 2006

Hoffman, B. (1998). Inside terrorism (2nd ed.). New York: Columbia University Press.

Hoffman, B. (2003). The logic of suicide terrorism. The Atlantic. Retrieved from https://www.theatlantic.com/magazine/archive/2003/06/the-logic-of-suicide-terrorism/302739/

Hoffman, B. (2006). Inside terrorism (2nd ed., expanded and revised). New York: Columbia University Press.

Hudson, R. A. (2002). Who becomes a terrorist and why: The 1999 government report on profiling terrorists. Guilford, CT: The Lyons Press.

Humphreys, A. (2006). One official's refugee is another's terrorist. National Post, January 17, 2006.

Kisangani, E., \& Nafziger, E. W. (2007). The political economy of state terror. Defense and Peace Economics, 18(5), 405-414.

Koffi, A. (2002). Press Conference with Koffi Anna \& FM Kamal Kharrezi. Retrieved January 26, 2002, from https://www.un.org/News/dh/latest/afghan/sg-teheran26.htm

Koffi, A. (2002). UNSG addresses the Security Council with a call on Counter-Terrorism Committee to Develop Long-Term Strategy to Defeat Terror. SC/7276, Retrieved January 18, 2002, from https://www.un.org/press/en/2002/SC7276.doc.htm 
Kperogi, F. (2018). Amnesty for Boko Haram? That’s unconscionable! International Centre for Investigative Reporting. Retrieved from https://www.icirnigeria.org/amnesty-for-boko-haram-thats-unconscionable/

MacAksill, E. (2010). Julian Assange like a high-tech terrorist. London: The Guardian.

McCabe, Z. E. (2013). Northern Ireland: The paramilitaries, terrorism, and September 11 . Retrieved from https://digitalcommons.du.edu/cgi/viewcontent.cgi?article=1481\&context=djilp

Nicolson, P. (2010). Domestic violence and psychology: A critical perspective. Taylor \& Francis. Retrieved from https://doi.org/10.4324/9780203093092

Obi, C. (2009). Nigeria's Niger Delta: Understanding the complex drivers of violent oil-related conflict. Africa Development, 34(2), 103-128.

Richardson, L. (2006). What terrorists want: Understanding the terrorist threats. London, UK: John Murray. ISBN 0-7195-6306-2

Rodin, D. (2006). Terrorism. In E. Craig (Ed.), Routledge encyclopedia of philosophy. London: Routledge. Retrieved from http://www.academicroom.com/topics/terrorism

Rudner, M. (2008). Protecting Canada's energy infrastructure against terrorism: Mapping a proactive strategy. Ottawa, Canada: Canadian Centre of Intelligence and Security Studies.

Shabad, G., \& Ramo, F. J. L. (1995). Political violence in a democratic state. In M. Crenshaw (Ed.), Terrorism in context. University Park: Pennsylvania State University.

Soyinka, W. (2012). Next phase of Boko Haram Terrorism-SHOLAADEBOWALE.COM - The World as I see it. Blog Archive, April 30, 2012.

Stille, A. (2003). Historians trace an unholy alliance: Religion as the root of nationalist feeling. The New York Times. Retrieved from https://www.nytimes.com/2003/05/31/arts/historians-trace-an-unholy-alliance-religion-as-the-root-of-nationalist-feeling.html

Van Krieken, P. (2010). Wesbster University Handbook on International Law (International regimes against terrorism).

Viotti, P. R., \& Kauppi, M. V. (2009). International relations and world politics: Security, economy, and identity. Upper Saddle River, NJ: Pearson, Prentice Hall.

Walzer, M. (2000). Just and unjust wars: A moral argument with historical illustrations (3rd ed.). New York: Basic Books.

Walzer, M. (2004a). Emergency ethics. In Arguing about war (pp. 33-50). New Haven and London: Yale University Press.

Walzer, M. (2004b). Terrorism: A critique of excuses. In Arguing about war (pp. 51-66). New Haven and London: Yale University Press.

Wikan, V. S. (2018). Is one man’s terrorist another man's freedom fighter? E-International Relations Students. Retrieved from https://www.e-ir.info/2018/11/29/is-one-mans-terrorist-another-mans-freedom-fighter/

Yoo, J. C., \& Ho, J. C. (2003). International law and the war on terrorism. Retrieved from https://www.law.berkeley.edu/files/yoonyucombatants.pdf 